УДК 373.1.02

UDC 373.1.02

DOI: $10.31475 /$ ped.dys.2020.28.02

IRYNA PITS,

Candidate of Pedagogical Sciences, Associate Professor (Ukraine, Chernivtsi, Yurii Fedkovych Chernivtsi National University, Kotsiubynskoho St., 2)

ІРИНА ПІЦ,

кандидат педагогічних наук, доцент (Украӥна, Чернівиі, Чернівецький національний університет ілені Юрія Федьковича, вул. Коиюбинського, 2)

ORCID: 0000-0002-7911-9922

HANNA BYHAR,

Candidate of Pedagogical Sciences, Associate Professor (Ukraine, Chernivtsi, Yurii Fedkovych Chernivtsi National University, Kotsiubynskoho St., 2)

ГАННА БИГАР, кандидат педагогічних наук, доцент (Украӥна, Чернівиі, Чернівецький національний університет ілені Юрія Федьковича, вул. Коцюбинського, 2)

ORCID: 0000-0002-4480-8293

KRYSTYNA SHEVCHUK,

Candidate of Pedagogical Sciences, Associate Professor (Ukraine, Chernivtsi, Yurii Fedkovych Chernivtsi National University,

Kotsiubynskoho St., 2)

КРИСТИНА ШЕВЧУК, кандидат педагогічних наук, доиент

(Украӥна, Чернівиі, Чернівецький національний університет ілені Юрія Федьковича, вул. Коцюбинського, 2)

ORCID: 0000-0002-9365-1456

OLESIA MAKOVIICHUK, Candidate of Pedagogical Sciences (Ukraine, Chernivtsi, Yurii Fedkovych Chernivtsi National University, Kotsiubynskoho St., 2)

ОЛЕСЯ МАКОВІЙЧУК,

кандидат педагогічних наук (Украӥна, Чернівиі, Чернівецький національний університет ілені Юрія Федьковича, вул. Коцюбинського, 2)

ORCID: 0000-0002-5247-8482

\title{
Pedagogical Conditions of Young Learners' Social Competence Formation in the Educational Process of Modern Ukrainian Primary School
}

\section{Педагогічні умови формування соціальної компетентності молодших школярів в освітньому процесі сучасної початкової школи}

Up to date, there are growing appeals for the Ukrainians' social security and protection under the conditions of increasing technogenic and growing informational load, leading to the risk of destroying personality. Previous studies have emphasized that social competence becomes more complicated as children grow older, and most intervention efforts for this age group target individual skills, the family, and the classroom setting. It is of critical value to nurture physically robust and socially developed fullfledged citizens, since there is a lack of the national rigorous study in the relevant domain. The aim of the research is to further extend and design social interaction research, the theoretical discourse and practical vision of fostering and improving primary schoolchildren's social competence in the new Ukrainian school setting. Taking a broad view on different approaches to the concept of social competence, we consider it a person's integrative capacity, formed in the process of his/her socialization experience. Thus, sharing societal norms and expectations, motives, values, emotional and practical 
skills, and knowledge, a person gains effectiveness of interaction with other people, independently finds constructive solutions to problems in real life situations, and rapidly adapts to new living conditions. Fostering and improving social competence in primary schoolchildren in the New Ukrainian School setting should become an indispensable part of school-parents' partnership in designing a variety of strategies and practices for improving schoolchildren's social knowledge and skills, and respectively making young learners balancing studies and social life.

Key words: social competence; primary schoolchildren; effective school-parents partnership; intervention; the New Ukrainian School; academic performance; self-awareness; knowledge and skills.

У статті розглянуто проблеми компетентнісного підходу у фбормуванні особистості молодшого школяра, яка здатна до соціальної діяльності, реалізацї особистісних задулів, шо $\epsilon$ основою освітнього напряму Нової української школи. На підставі аналізу наукових джерел у контексті дослідження розкрито сутність поняття "соціальна компетентність молодшого школяра", встановлено ї̈ як одну із базових компетентностей у розвитку особистості, а період молодшого шкільного віку визначено сенситивним для виникнення відповідних новоутворень, які е вкрай необхіднили для фборлування соціальної колпетентності.

На підставі теоретико-елпіричних досліджень обгрунтовано організаційно-педагогічні умови фбормування соціальної компетентності учнів молодшого шкільного віку, зокрема: побудова навчального процесу в інтерактивній фбормі; формування соціальної колпетентності молодших школярів засобали інфбормаційно-комунікаційних технологій; залучення учнів початкових класів до активного шкільного та громадського життя; утвердження партнерської взаемодії між вчителем та батьками та ін.

Ключові слова: компетентнісний підхід; соціальна колпетентність; молодші школярі; ефбективне партнерство між школою та батьками; салосвідолість; Нова украӥнська школа; акаделічна ефбективність; салосвідомість; знання та вміння.

Introduction / Вступ. Recent theoretical developments have revealed that the social processes taking place in Ukraine have prioritized the demand for the Ukrainians' constant updating of knowledge, citizens' mastering and gaining new skills for the cultivation of their sense of selfrealization and self-assertion in the society. Up to date, there are growing appeals for the Ukrainians' social security and protection under the conditions of increasing technogenic and growing informational load, leading to the risk of destroying personality.

One of the major topics to be investigated in this field is developing a socially competent person that has an ability to take critical perspective concerning a situation, learn from experiences, and apply that learning to the changes in social interactions. In other words, according to the Concept of the New Ukrainian School, primary schoolchildren should be prone to successfully and appropriately select and carry out their interpersonal goals as well as face the challenges and threats of the current realities (The Concept of «New Ukrainian School»..., 2016). Promoting effective tools for successful performance and creating a positive child-friendly environment should be of paramount importance for primary school teachers. Their priority is to develop a variety of strategies and practices for improving schoolchildren's social knowledge and skills, and respectively making young learners feel relaxed and accepted, recovered and fully engaged in the process of studies. The researchers speculate that children, struggling with self-regulation are at risk of experiencing peer rejection and academic difficulties.

There have been numerous studies to investigate social competence as social, emotional, cognitive, and behavioural skills needed for successful social adaptation (Semrud-Clikeman M., 2007).

The learning objectives should focus on young learners' training skills in problem solving, empathy, teamwork, emotional balance and self-discipline. Taking into consideration different research approaches to understanding the structure of teachers' professional competence on fostering and improving primary schoolchildren's social competence, we want to single out researches that delve into the essence and content of structural components of primary education teachers' professional competence.

A more comprehensive description of the problem of social competence development and motivational learning strategies can be found in the works of the leading foreign scholars.

K. Bradway underlines that cutting-edge trends in education focus on a child's preparedness for daily living and organize subject matter in terms of their interests, activities and social needs; consequently, it becomes desirable to include in classification criteria measures to their social attainment (Bradway K., 2015).

S. Magelinskaitè et al. define social competence as a person's ability to apply social skills effectively in order to reach his/her goals in social interactions. In their research, the authors predict that social competence results in better social relationships in school, which in turn reduces school anxiety and 
increase learning motivation and thus provides for better academic performance (Magelinskaite S. et al., 2014).

K. Tarasova addresses the problem children's intellectual development in primary school age. Stating that the social and emotional development of children is no less important than their academic performance. A hypothesis that socio-emotional competence (SEC) development in primary school children is a heterochronical process with the general level of socio-emotional competence increases with age appear to be well-grounded. According to the obtained results, there is no significant difference in the overall SEC level between the youngest and oldest participants. The scholar highlights that the level of SEC components, namely, self-awareness and social skills in the older children is significantly higher, that testifies to the fact that development of socio-emotional competence does not proceed evenly by all the SEC components in primary school age (Tarasova K., 2016).

A. Berhenke et al. tend to focus on children's emotional and behavioural responses to challenge as important indicators of school success. Their study demonstrates reliability and concurrent validity of a new observational assessment of motivation in young children (Berhenke A. et al. (2011).

In the G. Ladd et al. study, the problem of self-regulation has been identified as an important predictor of school readiness and academic achievement in young children. The researchers speculate that children, struggling with self-regulation are at risk of experiencing peer rejection and academic difficulties. They investigate the complex relations and mechanisms that influence early self-regulation and related outcomes will inform policy and practice in ways that help all children develop the selfregulation skills they need (Ladd G. et al., 2006).

According to C. Webster-Stratton \& M. J. Reid social-emotional skills curriculum is delivered as part of the statutory personal and social education curriculum that added benefits for children with identified behavioural, social, and/or emotional difficulties. The scholars conclude that targeted schoolbased social-emotional intervention delivered by teachers, alongside a similar class-wide universal curriculum prove to be successfully aligned with young high-risk children (Webster-Stratton C., \& Reid M. J., 2004).

N.Bernard discloses the problem of the non-academic, social-emotional factors that contribute to student academic achievement, including the cognitive-behavioural characteristics of underachieving students and those with learning disabilities; of particular value for our embracing the problem is his «You Can Do It! Education» (YCDI) theory of achievement. The scientist has presented derivative research on social-emotional capabilities, namely, academic confidence, work persistence, work organization, getting along, emotional resilience, producing considerable achievement and develops students' social-emotional competence (Bernard N., 2006).

It should be emphasized that the problem of adult adjustment and integration is deeply rooted in laying the grounds of emotional quotient and social competence in early childhood. It is of critical value to nurture physically robust and socially developed full-fledged citizens, since there is a lack of the national rigorous study in the relevant domain.

Aim and Tasks / Мета та завдання. The aim of the research is to further extend and design social interaction research, the theoretical discourse and practical vision of pedagogical conditions for fostering and improving primary schoolchildren's social competence in the new Ukrainian school setting.

Objectives of the research are:

1) to analyze and systematize, targeted in scientific and methodological literature, theoretical approaches to the social constructions of the concept of «social competence»;

2) to study the basic principles of fostering and improving social competence of primary schoolchildren in the New Ukrainian School setting;

3) to identify and outline a conceptual model for primary school children's social competence in the New Ukrainian School settings.

Methods / Методи. To judge the validity of our study we would rather provide a clear and precise description of the research methods as followed: theoretical analysis and synthesis of social skill training, generalization of the body of specialized and documentary evidence, didactic andempirical studies of the influence of pedagogical interference in fostering schoolchildren's social competence (observation and teachers' questioning).

Results / Результати. Importantly, Ukraine's education system reforming is an integral part of the all-encompassing reform process in the country and aims at improving the quality of education, improving equality of opportunities, and fostering social and emotional competence in young people. According to the Law of Ukraine "On Education", "A goal of the education is comprehensive development of the human being as a personality and as the supreme value of the society, development of its talents, intellectual, creative and physical abilities, formation of values and competences necessary for successful self-realization, raising responsible citizens capable to make a conscious choice and 
channel their activities for the good of other people and the society; and enriching the intellectual, economic, creative, cultural potential of the Ukrainian people on this basis, improving an educational level of the people in order to ensure Ukraine's sustainable development and its European choice» (Law of Ukraine «On Education»..., 2017).

The topicality of the researched problem lies in the core principle of modern society that needs to train and educate intelligent, emotionally balanced and socially competent people, capable of taking responsibility for their decision-making. Of particular importance for educators is the fact that exploring the social and emotional sphere in primary school is an issue of equally important value for both teachers and psychologists and caregivers due to increasing social demands for socio-emotional competence (SEC) as a basic element of conscious management of social behaviour (Tarasova K., 2016).

The term competence is widely used by modern scientists; it mainly defines new missions of the New Ukrainian School by showing relevant outcomes in their academic performance. In the modern society, the specific knowledge and skills will not definitely provide with decent place in life. The universal multitasking, examples of different activities, flexibility and critical thinking, the ability to work with information and interaction with others are popular and useful skills instead. T. Smahina remarked that competence is a specific ability that can effectively solve problems that come up in real life situations (Smahina T., 2015). The new State Elementary Education Standard defines competence as the integrated ability of an individual's learning process, which integrates the knowledge, experience, values and attitudes that can be fully implemented (Smahina T., 2015).

In the light of recent studies, the concept of competence refers to an individually or interindividually available collection of prerequisites for successful action in meaningful task domains. A competency is more than just knowledge and skills. It involves the ability to meet complex demands, by drawing on and mobilizing psychosocial resources (including skills and attitudes) in a particular context. For example, the ability to communicate effectively is a competency that may draw on an individual's knowledge of language, practical Information Technology skills and attitudes towards those with whom he or she is communicating. Defining such competencies can improve assessments of how well prepared young people and adults are for life's challenges, as well as identify overarching goals for education systems and lifelong learning (Rychen D. S., \& Salganik L.H. (Eds.), 2005).

During the educational process, primary school children should acquire key competences that focus on their personal, social and intellectual development. This research highlights competence that defines a holistic capacity, combining personal qualities and experience, acquired during academic performance and the necessity of taking appropriate action to solve problems at different stages of life.

In the context of developing and implementing the "skills approach» in education, well-known scientists attribute the social competence of an individual to the main skills as well as their intellectual, social, cultural, salutogenic, digital literacy and tech-savvy skills and competencies.

According to the concept of the New Ukrainian School, social competence is defined as the ability to cooperate for a particular outcome and the capability to reach compromises.

Taking a broad view on different approaches to the concept of social competence, we consider it a person's integrative capacity, formed in the process of his/her socialization experience. This life experience in the process of which a person acquires and shapes his/her cultural elements the individual's self and personality. Thus, sharing societal norms and expectations, motives, values, emotional and practical skills, and knowledge, a person gains effectiveness of interaction with other people, independently finds constructive solutions to problems in real life situations, and rapidly adapts to new living conditions and makes him/herself.

According to O. Galakova, fostering and development of social competence are directly influenced and affected by such personal characteristics as integrity, self-control, vigour and enthusiasm, emotional culture, authenticity and sensitiveness, tact, honesty, tolerance and caregiving, punctuality and responsibility. From the short review above, key findings emerge - the fostering of the following qualities are crucial for primary schoolchildren to develop positive relationships with peers and adults (Galakova O., 2013).

While researching a person's social competence, regardless of the terms to describe this concept key skills, key qualifications or essential competencies or key competencies, basic skills, key abilities, key skills - both foreign and Ukrainian scientists recognize it as one of the critical competences in a personal development. The result now provides evidence to the fact that all components are social, in the broad sense of the term, because a society produces and fosters person's social competence skills that prove of value in wringing social meaning (Zymnia I., 2004).

From psychological and pedagogical perspectives, this yields increasingly worthy results on data that the essence of the concept of social competence of primary schoolchildren bears multifaceted consideration; for instance:

- an integral feature of students' personality to represent the system of their knowledge, abilities 
and skills acquired in the course of learning and necessity to model their own behaviour; the ability to embrace the surrounding and to build a system of relationships and interactive communication (Korotina Yu., 2011);

- a structural component in the established system of the children's civility and culture, equally satisfying their needs and solving organizational problems that are regulated by a student's social background, and represents a harmonious blending of the defining components: driving forces and urges, knowledge and a personal activity (Nikolaescu I., 2014);

- an ability of primary school students to assess and validate their own self-worth and dignity; to equally recognize the importance and significance of others; develop cooperative spirit in children to socialize with their peers and adults; knowledge of interaction behaviour; competence of conflictresolving; relational developmental systems framework; tolerance and empathy and responsibility for their actions(Galakova O., 2013).

Previous studies have emphasized that social competence has been conceptualized as consisting of six categories of competence: adoption of social values, development of a sense of personal identity, acquisition of interpersonal skills, learning how to regulate personal behaviour in accord with societal expectations, planning and decision-making, and development of cultural competence (Kostelnik M., 2002).

In any early childhood education program, adults and children interact within an environmental context. Broadly defined, this context includes the physical structures, objects, and organization of the classroom; the temporal organization of routines and activities; and the emotional climate of the setting. These elements can be manipulated to create the most optimal setting for children's social competence to flourish (Han N. S., \& Kemple K. M., 2006).

We characterize the social competence of primary school-age children by their ability to interact effectively with others and to solve social problems that they encounter, based on acquired knowledge and personal experience in accordance with their age characteristics. This competence determines the ability of the pupils to live a full life in society, the ability to adapt to changing environmental conditions.

Discussion / Обговорення. The primary school age is a sensitive and vulnerable period of considerable personal development and growth, which is essential construct for their being socially competent and highly independent. In addition, primary school children's social competence becomes their push and motivation for being socially important and successful. Furthermore, primary school-age is the stage of their aiming to achieve productive and praiseworthy outcomes; parental appraisal and support - a significant age interaction effect was found for the association between intrusiveness and social; the ability for adequate self-esteem; developing interactive dialogic relationships; and simultaneous rapprochement with a group of peers; mastering etiquette, where social skills of constructive interaction become indispensable; awareness of the possibility of influencing the decision of many life circumstances, etc. (Bibik N. et al., 2004).

Among the main components of the primary-school-aged social competence constructs, we can mention as followed:

- the cognitive component includes the understanding of socially acceptable standards of life in a society (expressed in terms: "may or may not», "possible or impossible», "good or bad»; "must or have to»); social interaction mindfulness; awareness of ones' activity impact on the emotional state of others; the art of communication as well as age and gender sensitivity, etc.

- the emotionally-focused component includes a child's empathy to his/her classmates and adults; consideration of tolerance; social responsibility; responsiveness, compassion, sympathy; respecting others; self-esteem, self-confidence; positive motivation to win and succeed in life;

- the behavioural component implies the shaping of skills to act appropriately in accordance with socially accepted rules of conduct; choice of solving conflict and problematic situations by optimal ways; searching for the necessary information, providing dialogic interaction with adults and peers; system of «peer-mediated», «adult-mediated» intervention; cooperation; developing self-discipline and perseverance skills.

We believe that we have discovered an innovative solution to singling out the levels of pupils' social competence developing: a socially amorphous (low), a socially adaptive (moderate), and a socially creative (high) level.

Socially amorphous and anomic is the level of a child's social passivity. One of the reasons is the inability of the individual to solve problems independently. Being in such a state, the pupil seeks resources, primarily, to ensure his own security, without showing any initiative, absolutely relying on others. A pupil, characterised by a socially amorphous level, is specified by a lack of motivation; playing 2-3 major roles (pupil, family member, friend); making a few friends (1-2), where he/she often plays a subordinate role; being aware of human values and virtues, still lacks enthusiasm to realize them; 
shallow knowledge on the world and relationships; poorly developed social skills to defend his/her own opinion; the pupil is low-motivated, is able to work in a team, but adheres to avoiding the conflict tactics. The pupil is not ready to change something, but is satisfied with the existing relationships. Their as usually are low. From a socially amorphous level, a child can either descend to the stage of maladaptation (under unfavourable socio-psychological conditions), and rise to socially desirable levels of social competence (if his own resources are mobilized and appropriate social and pedagogical assistance is provided).

In our opinion, a socially adaptive level is the basic level of a primary school-aged social competence. Noteworthy, this level includes understanding of his/her own social role and ability to get used to social circumstances, not passively, but by making active choice while using different communication techniques. The basis of this social competence type is the life goals of well-being and proper lifestyle. Students are foremost focused on the harmony of relationships with their closest environment (family, teachers, friends, etc.) and the balance of educational and leisure activities (participation in societies and clubs), etc.

Formation of the primary schoolchildren's' social competence can be characterized as an appropriate one, socially and pedagogically desirable. The students of this group possess the following features: social activity, harmonious relations with others, role flexibility, desire to expand the role repertoire; skills of positive self-presentation that are developed enough; ability to clearly set tasks and the availability of personal resources to accomplish them; lexically and internationally rich, figurative language. Students can often predict conflict situations and take measures to prevent them, and, effectively resolve it in case of such situation. They have quite wide circle of contacts. Educational achievements of these children are satisfactory and high.

The socially creative level is considered the highest social competence manifestation, which provides students' self-creation, their efforts to positively change the environment, believing that such change will benefit both the classmates and the students themselves. Such students aim at changing their social setting by participating in various events not only within the school but also at the city, regional level.

When social competence levels of the primary-school-age children are determined, we completely understand that the line is fairly conditional. As far as students cannot avoid conflicts and difficulties, they can perceive, realize and estimate these conflicts, productively resolve them according to a person's general purposes and moral ideals, reaching more and more development stages and levels. Such ideas should be taken into consideration while working with primary school pupils, who are in the process of values and community standards digestion, searches and social tries.

Fostering and improving primary school children's social competence requires a systematic approach, and that is why we provide the organizational and pedagogical setting. The usage of interactive techniques of a primary school learning process is considered the one of these conditions.

The primary school-aged social competence formation is contextual and long-termed learning process. Thus, intrusiveness in the process of mastering disciplines will help to develop a productive interpersonal interaction within students and will be contextual, regardless the subject.

Learning process formation in an interactive form changes its usual format: the process is created not from theory to practice, but from the new skill formation to its theoretical understanding. Especially valuable is that the social competence formation in this context often doesn't follow rules imposed from above, it breaks internal resistance and attempts to treat the process formally, as far as a teacher is not the only source of knowledge and experience, but a social awareness acquisition and skill formation.

Communicating with peers whilst practicing interactive teaching methods, elementary school pupils learn to use the language appropriately and relevantly in specific circumstances (concisely express their thoughts, needs, intentions, requests, etc.) using both linguistic and non-linguistic (facial expressions, body language), motion along with the timbre and tone of their voice (Yermakov I., 2006).

In terms of interactive learning, young children learn to control themselves and their anxieties; to manage mental state, body, voice, facial expressions; mood, thoughts, feelings; get rid of the muscle tension. Pupils develop the ability to solve moral problems arising from the age and psychological properties of children of this age. Such features consist in the pursuit of elementary school pupils to awareness, self- knowledge through comparison of themselves with peers and adults. As a result, of communication with others the developing process of evaluation of self and others occurs. However, quite often, the discovery of one's personal «ego» evokes deep feelings. The reason for all this may be that its internal state does not correlate with occurring actions. Meanwhile another particular quality of elementary school pupils is their desire to understand the causes of their conflicts, failures or successes and difficulties.

With the use of interactive learning technologies (techniques), the pupil learns to make conscious choices among a wide range of alternatives and take responsibility for making independent decisions. 
The next institutional demand for the development of social competence of younger pupils, in our opinion, is the improvement of social abilities of pupils using information and communication technologies (techniques) (ICT).

With the admission of the child to school, she/he gets the possibility of uncontrolled access to the world modern information through the mobile phone, tablet and more. However, the lack of real social experience makes this interaction offhand, and the overuse of ICT by the child can adversely affect physical, psychological and social development. In addition, it is necessary to develop in children a value-based attitude to information rather than to various ICTs.

Given the problems outlined, the need to harmonize media influences on elementary school pupils becomes more important. Since the media is an essential component of socialization in an information society, we believe that a young pupil should acquire knowledge of the true name, right purpose, history; positive and negative impact recent media has on the individual, rules of behaviour in the modern field of information.

Due to the popularity of many social networks and communication within the modern world of information, young schoolchildren should master the skills of communication in it to prevent possible hostility (swindle, cyber-bullying, paedophilia) at a particular stage of personal development and in the future. In addition, at an advanced age, there is a need to develop the ability to use one's free time outside of the latest media, to prevent dependence on the present informational technologies in the further life.

It is critical to develop the ability to analyse (as reflection builds up at a certain age) and to distinguish between truthful and false information when searching for it and communicating in a modern informational space.

There is a necessity of appropriate social environment setting besides primary pupils' social competence development, i.e. modern informational environment at school and families providing modern informational space for a child.

Social psychological service, library and media are considered as junior pupils' informational environment, since they are supposed to have permanent access to Information technology study and computer technologies; since computer sciences are included in the curriculum of the second year of a primary school. In this context, school clubs aimed at mastering the skills of using IT and the Internet on their own, moreover, school media (newspaper, radio, television or website etc.) whereas the pupils are involved not only in media using but also in their designing.

To date, the pupils' informational environment in family is much different from the environment of junior pupil at primary school. Pupils have an opportunity to use media texts suitable to their age features and needs, to meet their mental, moral and social development needs, unlike the family media texts, aimed at the asocial knowledge, features, behaviour, motivation and values, etc.

Therefore, to summarise, we can state that modern informational environment of educational institution has a socially educational objective. Consequently, there is a need of the special socialpedagogical activity implementation in balanced media influence, especially on primary schoolchildren in order to increase positive aspects of new media influence and overcut the negative effect at school frame.

Next educational condition is the children's engagement in the public life to shape their social competence. Primary school age is the first stage of systematic pupils' engagement into public life. There is a number of personal development necessary for junior pupils' social competence forming at this very period.

The determined factor of primary pupils' social competence formation is the proactive socialization, which is a personal adaptation to the society requirements that provides its successful functioning in the environment. In socialization process, a young person should learn and meet the society requirements. The outcome is the forming collective consciousness; gain skills of a person-environment fit and improve social roles performances.

Consequently, such tasks have to be realized through social practice, child's involvement in various societies, public organizations, and school self-government. Primary schoolchildren's engagement in the students' self-government promotes social competences forming and developing; the pupils' ability of taking responsibility, mutually make decision, participate in different social projects, resolve conflicts in a civilised way, etc.

The primary schoolchildren's engagement is manifested in various forms, in particular, social events (charity and caregiving; participating in environmental projects; conducting social surveys, etc.; for example «Book Crossing», "Visit a Library - Discover the World of Reading», "Plant a Tree», "Literary Quizzes", "Recognize the Beauty and Euphony of the Mother Tongue», festivals "Family Reading Library», "New Year Fairy Tales»): pupils' newspapers with various columns (e.g. "Face to Face», "A Schoolchild»); social projects (e.g. "Nature and Us», "Seven Treasures of Humanity»); as well as 
literature clubs, language forums, discussions, literature quizzes with parents' involvement, etc.

The establishment of a healthy Parent-Teacher Partnership is one of significant push-pull factors and pretexts for effective school-home communication in process of the of primary school pupils' social competence fostering and development.

From a legal perspective, two-way communication, to be more precise, parent engagement and successful parent-teacher partnerships result in improved educational outcomes for students. Importantly, the National Strategy of Education Development in Ukraine for 2012-2021 set the perspective goals to substantially advance educational process, namely, «to develop an efficient system of national education based on universal, multicultural, moral values; to guarantee physical, moral and spiritual, cultural development of a child; to mould a socially mature creative personality, a citizen of Ukraine and the world; to prepare young people for making a conscious choice», and also" to ensure the dominant responsibility of the family for children's education and upbringing» (National Strategy for..., 2017).

To our knowledge, a core construct of the "parent-school» partnership should be an educational institution, since the effectiveness of primary school pupils' education depends on teachers' capacity to maintain close ties with children's parents; to bridge the gaps of family and school, harmonize their relationship with the consideration of psychological and pedagogical factors influencing the social formation of a personality.

Constructive teacher-parent partnership is the most efficient in terms of achieving the pertinent outcome. The educational process, both in the family and in the educational institution, must be clearly designed and consistent.A collaborative and cooperative partnership focuses on specific, positive strategies to help primary school children make the best of their potential. Nowadays, The Ukrainian society undergoes social and economic crises. Every year more and more children find themselves in difficulty due to the lack of parental care and rapport. Several studies have found that it is favourable and beneficial for all parts: teachers, parents and children to apply multi-modal approach to foster partnership strategies to support children, to promote positive outcomes and get them ready and prepared for adult responsible and proactive life.

To summarise, building a healthy and effective parent-school relationship grounds on:

- teachers-parents educational outreach and intervention, involving parents' core knowledge, attitude and practices to foster children's social competence, building the foundation for all forms of parents' involvement in education (different events and activities: pedagogical school for parents, psychological and pedagogical counselling and training, practical tasks for parents, teachers-parents conferences with children, etc.);

- consistent and efficient teacher's influence on providing two-way information and improving the link between classroom learning activities and at-home learning accomplishments; encouraging the parents' interest their children's achievements, facilitating the establishment of empathetic and tolerant relationships between peers;

- intensification of cooperation in the system "teacher-parents-pupil», aimed at building dialogic interaction in these relations, based on the individual approach to each pupil and the principles of pedagogy of partnership and personal-oriented interaction, mutual responsibility of both teachers and parents (events and avenues: forums, teamwork, extra-curricular activities).

Conclusions / Висновки. The evidence from this study suggests that primary school period is extremely important for every single child in terms of all vital competences formation, where social one is of paramount importance. The main objective is to nurture and educate a full-fledged socially competent citizen. Significantly, all participants' joint efforts in the educational process yield the most significant productive outcomes. Pupils fostered in such a partnership will definitely be ready for an effective rapport in their nearest future.

There is much evidence that certain socio-emotional abilities increase and strengthen at the primary school age. The data testify that the general hypothesis of our research testifies to the fact that teachers-parents' top priority is to support the children's independence, the learning objectives should focus on primary schoolchildren's training skills and competences in problem solving, empathy, teamwork, emotional balance and self-discipline. Promoting effective tools for successful performance and creating a positive child-friendly environment should be of paramount importance for primary school teachers. Fostering and improving social competence in primary schoolchildren in the New Ukrainian School setting should become an indispensable part of school-parents partnership in designing a variety of strategies and practices for improving schoolchildren's social knowledge and skills, and respectively making young learners balancing studies and social life. We hope that further research on primary schoolchildren social competence will confirm our findings. 


\section{References:}

Berhenke, A., Miller, A. L., Brown, E., Seifer, R., \& Dickstein, S. (2011). Observed Emotional and Behavioral Indicators of Motivation Predict School Readiness in Head Start Graduates. Early Childhood Research Quarterly, 26, 430441 [in English].

Bernard, N. E. (2006). It's Time We Teach Social-Emotional Competence as Well as We Teach Academic Competence. Reading \& Writing Quarterly, 22, 103-119 [in English].

Bibik, N. M., Vashchenko, L. S., Lokshina, O. I., Pometun, O. I., \& Savchenko, O. Ya. (2004). Kompetentnisnyi pidkhid $v$ suchasnii osviti: svitovyi dosvid ta ukrainski perspektyvy [Competence Approach in Modern Education: World Experience and Ukrainian Perspectives]. Kyiv: K.I.S. [in Ukrainian].

Bradway, K. (2015). Social Competence of Grade School Children. The Journal of Experimental Education, 6, 326331. Retrieved from https://doi.org/10.1080/00220973.1938.11010095 [in English].

Galakova, O. V. (2013). Razvitie socialnoj kompetentnosti mladshyx shkol'nikov vo vneurochnoj deyatel'nosti [Development of Social Competence of Primary School Students in Extracurricular Activities]. (Candidate's thesis). Moscow [in Russian].

Han, H. S., \& Kemple, K. M. (2006). Components of Social Competence and Strategies of Support: Considering What to Teach and How. Early Childhood Education, 34, 241-246. Retrieved from https://doi.org/10.1007/s10643-0060139-2 [in English].

Kontseptsiya Novoi Ukrainskoi Shkoly [The Concept of "New Ukrainian School»]. (2016). Retrieved from https://www.kmu.gov.ua/storage/app/media/reforms/ukrainska-shkola-compressed.pdf [in Ukrainian].

Korotina, Yu. V. (2011). Formirovanie socialnoj competentnosti mladshy'x shkol'nikov sredstvami uchebny'x predmetov [The Formation of Social Competence of Primary Schoolchildren by Means of Educational Subjects]. (Extended abstract of Candidate's thesis). Tambov [in Russian].

Kostelnik, M. J., Whiren, A. P., Soderman, A. K., Stein, L. C., \& Gregory, K. (2002). Guiding Children's Social Development: Theory to Practice. (4th ed.) New York [in English].

Ladd, G. W., Herald, S. L., \& Kochel, K. P. (2006) School Readiness: Are there Social Prerequisites? Early Education and Development, 77 (1), 115-150 [in English].

Magelinskaitè, Š., Kepalaitè, A., \& Legkauskas, V. (2014). Relationship Between Social Competence, Learning Motivation, and School Anxiety in Primary School. Procedia: Social and Behavioral Sciences, 116, 2936-2940 [in English].

Natsionalna stratehiiia rozvytku osvity v Ukraini na 2012-2021 roky [National strategy for the development of education in Ukraine for 2012-2021]. Retrieved from http://oneu.edu.ua/wp-content/uploads/2017/11/nsro_1221.pdf [in Ukrainian].

Nikolayescu, I. O. (2014). Formuvannia sotsialnoi kompetentnosti uchniv zahalnoosvitnikh navchalnykh zakladiv vidpovidno do vymoh novykh derzhavnykh osvitnikh standartiv: naukovo-metodychnyi posibnyk [Formation of Social Competence of Students of Secondary Schools in Accordance with the Requirements of New State Educational Standards: Scientific and Methodological Manual]. Cherkasy: OIPOPP [in Ukrainian].

Rychen D. S., \& Salganik L. H. (Eds.). (2005). The Definition and Selection of Key Competencies (Executive Summary). Retrieved from https://www.oecd.org/pisa/35070367.pdf [in English].

Semrud-Clikeman, M. (2007). Social Competence in Children. New York: Springer [in English].

Smahina, T. (2015). Poniattia ta struktura sotsialnoi kompetentnosti uchniv yak naukova problema [The Concept and Structure of Social Competence of Students as a Scientific Problem]. Visnyk Zhytomyrskoho Derzhavnoho Universytetu. Pedahohichni nauky - Bulletin of Zhytomyr State University. Pedagogical sciences, 50, 138-142 [in Ukrainian].

Tarasova, K. (2016). Development of Socio-emotional Competence in Primary School Children. Procedia: Social and Behavioral Sciences, 233, 128-132. Retrieved from https://doi.org/10.1016/j.sbspro.2016.10.166 [in English].

Webster-Stratton, C., \& Reid, M. J. (2004). Strengthening Social and Emotional Competence in Young Children The Foundation for Early School Readiness and Success: Incredible Years Classroom Social Skills and Problem-Solving Curriculum. Infants \& Young Children, 17, 96-113. Retrieved from https://doi.org/10.1097/00001163-200404000-00002 [in English].

Yermakov, I. (2006). Fenomen competentnistno-oriyentovanoi osvity [The Phenomenon of Competence-Oriented Education]. Shkola - School, 12, 5-7 [in Ukrainian].

Zakon Ukrainy "Pro Osvitu» [Law of Ukraine "On Education»]. № 2145-VIII. (2017). Retrieved from https://zakon.rada.gov.ua/laws/show/2145-19 [in Ukrainian].

Zimnyaya, I. A. (2004). Klyuchevy'e kompetentnosti kak rezul'tativno-celevaya osnova kompetentnostnogo podxoda $v$ obrazovanii [Key Competencies as an Effective and Targeted Basis of the Competency-Based Approach in Education]. Moscow [in Russian].

\section{Список використаних джерел і літератури:}

Berhenke, A., Miller, A. L., Brown, E., Seifer, R., \& Dickstein, S. (2011). Observed Emotional and Behavioral Indicators of Motivation Predict School Readiness in Head Start Graduates. Early Childhood Research Quarterly, 26, 430441 [in English].

Bernard, N. E. (2006). It's Time We Teach Social-Emotional Competence as Well as We Teach Academic Competence. Reading \& Writing Quarterly, 22, 103-119 [in English].

Бібік, Н. М., Ващенко, Л. С., Локшина, О. І., Пометун, О. І., \& Савченко, О. Я. (2004). Компетентнісний підхід в сучасній освіті: світовий досвід та українські перспективи. Київ: К.I.C. [in Ukrainian].

Bradway, K. (2015). Social Competence of Grade School Children. The Journal of Experimental Education, 6, 326331. Retrieved from https://doi.org/10.1080/00220973.1938.11010095 [in English].

Галакова, О. В. (2013). Развитие социальной колпетентности младших икольников во внеурочной деятельности. (Дисс. канд. пед. наук). Москва [in Russian].

Han, H. S., \& Kemple, K. M. (2006). Components of Social Competence and Strategies of Support: Considering What to Teach and How. Early Childhood Education, 34, 241-246. Retrieved from https://doi.org/10.1007/s10643-0060139-2 [in English]. 
Концепиія Нової Украйнської школи (2016). Взято з https://www.kmu.gov.ua/storage/app/media/reforms/ukrainskashkola-compressed.pdf [in Ukrainian].

Коротина, Ю. В. (2011). Форлирование социальной колпетентности младших школьников средствали учебных предлетов. (Автореф. дисс. канд. пед. наук). Тамбов [in Russian].

Kostelnik, M. J., Whiren, A. P., Soderman, A. K., Stein, L. C., \& Gregory, K. (2002). Guiding Children's Social Development: Theory to Practice. (4th ed.) New York [in English].

Ladd, G. W., Herald, S. L., \& Kochel, K. P. (2006) School Readiness: Are there Social Prerequisites? Early Education and Development, 77 (1), 115-150 [in English].

Magelinskaitè, Š., Kepalaitè, A., \& Legkauskas, V. (2014). Relationship Between Social Competence, Learning Motivation, and School Anxiety in Primary School. Procedia: Social and Behavioral Sciences, 116, $2936-2940$ [in English].

Національна стратегія розвитку освіти в Україні на 2012-2021 роки. Взято з http://oneu.edu.ua/wpcontent/uploads/2017/11/nsro_1221.pdf [in Ukrainian].

Ніколаеску, І. О. (2014). Формування соціальної колпетентності учнів загальноосвітніх навчальних закладів відповідно до нових вимог Державних освітніх стандартів: наук.метод. посіб. Черкаси: ОІПОПП [in Ukrainian].

Rychen D. S., \& Salganik L. H. (Eds.). (2005). The Definition and Selection of Key Competencies (Executive Summary). Retrieved from https://www.oecd.org/pisa/35070367.pdf [in English].

Semrud-Clikeman, M. (2007). Social Competence in Children. New York: Springer [in English].

Смагіна, Т. (2015). Поняття та структура соціальної компетентності учнів як наукова проблема. Вісник Житомирського державного університету. Педагогічні науки, 50, 138-142 [in Ukrainian].

Tarasova, K. (2016). Development of Socio-emotional Competence in Primary School Children. Procedia: Social and Behavioral Sciences, 233, 128-132. Retrieved from https://doi.org/10.1016/j.sbspro.2016.10.166 [in English].

Webster-Stratton, C., \& Reid, M. J. (2004). Strengthening Social and Emotional Competence in Young Children The Foundation for Early School Readiness and Success: Incredible Years Classroom Social Skills and Problem-Solving Curriculum. Infants \& Young Children, 17, 96-113. Retrieved from https://doi.org/10.1097/00001163-200404000-00002 [in English].

Срмаков, I. (2006). Феномен компетентнісно-орієнтованої освіти. Школа, 12, 5-7 [in Ukrainian].

Закон України "Про освіту». № 2145-VIII. (2017). Взято 3 https://zakon.rada.gov.ua/laws/show/2145-19 [in Ukrainian].

Зимняя, И. А. (2004). Ключевые колпетентности как результативно-целевая основа колпетентностного подхода в образовании. Москва [in Russian].

Дата надходження статті: «19» березня 2020 р.

Стаття прийнята до друку: «12» травня 2020 р.

Піц Ірина - доцент кафедри педагогіки та методики початкової освіти Чернівецького національного університету імені Юрія Федьковича, кандидат педагогічних наук, доцент

Pits Iryna - Assistant Professor of the Department of Pedagogy and Methodology of Primary Education of Yurii Fedkovych Chernivtsi National University, Candidate of Pedagogical Sciences, AssociateProfessor

Бигар Ганна - доцент кафедри педагогіки та методики початкової освіти Чернівецького національного університету імені Юрія Федьковича, кандидат педагогічних наук, доцент

Byhar Hanna - Assistant Professor of the Department of Pedagogy and Methodology of Primary Education of Yurii Fedkovych Chernivtsi National University, Candidate of Pedagogical Sciences, AssociateProfessor

Шевчук Кристина - доцент кафедри педагогіки та методики початкової освіти Чернівецького національного університету імені Юрія Федьковича, кандидат педагогічних наук, доцент

Shevchuk Krystyna - Assistant Professor of the Department of Pedagogy and Methodology of Primary Education of Yurii Fedkovych Chernivtsi National University, Candidate of Pedagogical Sciences, AssociateProfessor

Маковійчук Олеся - асистент кафедри педагогіки та методики початкової освіти Чернівецького національного університету імені Юрія Федьковича, кандидат педагогічних наук

Makoviichuk Olesia - Assistant of the Department of Pedagogy and Methodology of Primary Education of Yurii Fedkovych Chernivtsi National University, Candidate of Pedagogical Sciences

\section{Цитуйте ию статтю як:}

Піц, І., Бигар, Г., Шевчук, К., \& Маковійчук, О. (2020). Педагогічні умови формування соціальної компетентності молодших школярів в освітньому процесі сучасної початкової школи. Педагогічний дискурс, 28, 13-22. doi: 10.31475/ped.dys.2020.28.02.

\section{Cite this article as:}

Pits, I., Byhar, H., Shevchuk, K., \& Makoviichuk, O. (2020). Pedagogical Conditions of Young Learners' Social Competence Formation in the Educational Process of Modern Ukrainian Primary School. Pedagogical Discourse, 28, 13-22. doi: 10.31475/ped.dys.2020.28.02. 